\title{
Monitoring and Tracking the Economics of Information in the Convention on Biological Diversity: Studied Ignorance (2002-2011)
}

\author{
Omar Oduardo-Sierra ${ }^{1}$, Barbara Ann Hocking ${ }^{2} \&$ Joseph Henry Vogel ${ }^{3}$ \\ ${ }^{1}$ Department of Political Science, University of Puerto Rico-Río Piedras, USA \\ ${ }^{2}$ Honorary Research Fellow, Riawunna Institute, University of Tasmania and QUT Faculty of Law, Australia \\ ${ }^{3}$ Department of Economics, University of Puerto Rico-Río Piedras, USA \\ Correspondence: Joseph Henry Vogel, Department of Economics, University of Puerto Rico-Río Piedras, \\ PO Box 9021833, San Juan, PR 00902-1833, USA. E-mail: josephvogel@usa.net
}

Received: February 2, 2012 Accepted: February 10, 2012 Online Published: May 11, 2012

doi:10.5539/jpl.v5n2p29 URL: http://dx.doi.org/10.5539/jpl.v5n2p29

Support has been provided by the IGERT Grant of the National Science Foundation (0801577) and the Linkage International Grant of the Australian Research Council (LX0881935). Any opinions, findings, conclusions or recommendations expressed are those of the authors and do not necessarily reflect the views of the NSF or ARC (Sponsoring information)

\begin{abstract}
From the outset of the 1992 Convention on Biological Diversity (CBD), the application of the economics of information to "access to genetic resources" appears in the published literature. The implications for "the fair and equitable sharing of benefits" (ABS) run counter to the policy discussion in the ten Conferences of the Parties to the CBD (1993-2010). Meanwhile the economics of information has become mainstream as witnessed by the 2001 Nobel Memorial Prize and its incorporation in introductory textbooks by 2001. Through Google, Google Scholar and LexisNexis, the ABS literature is searched including and excluding the "economics of information" for the period 2002-2011. The hits differ by three to four orders of magnitude without any evidence of subsiding over the period examined. Such studied ignorance is distinguished from the mere lack of due diligence by exploring two examples from academic superstars who ironically have complained about their scholarship being ignored.
\end{abstract}

Keywords: access to genetic resources and benefit sharing, biopiracy, bioprospecting, biodiversity cartel, due diligence, economic rents

\section{Introduction}

Scholars across the disciplines are elaborating the scientific, technical and socio-economic issues of the 1992 United Nations Convention on Biological Diversity (CBD). A systematization of the literature reveals a studied ignorance of the economics of information in discussions about "ABS" (access to genetic resources and the fair and equitable sharing of benefits). Because the claim implies intent, a distinction must be drawn between studied ignorance and the mere lack of due diligence. Similarly, any claim about due diligence must allow a reasonable passage of time for ideas to penetrate the public sphere. So the classification of absence of the economics of information as either studied ignorance or lack of due diligence begins on 1 January 2002, approximately ten years after signature of the CBD by 100 heads of state at the Earth Summit, Rio'92. Results of the literature search are presented for the ten year period 1 January 2002 to 31 December 2011.The purpose of such monitoring and tracking is to facilitate due diligence and help end the studied ignorance that prevents ABS.

\section{Benchmark Dates for the Economics of Information}

No one likes being ignored and academics are especially sensitive. A decent showing in the citation indices enables promotion and tenure; copious citations drive the "star system" of endowed appointments. Nevertheless, promising scholars are reluctant to protest having been studiously ignored for fear of being ridiculed as "faux superstar[s]"--Cary Nelson and Stephen Watt's description of the self-promoting professor (1999 p. 275). Because of such reluctance, protests usually emanate from senior scholars who have already achieved some 
stardom no matter how faint their luminosity. Any ridicule of the protesting scholar would backfire by raising awareness of the scholarship studiously ignored.

In the now landmark 1961 article "The Economics of Information," George J. Stigler, then a rising star, laments"[o]ne should hardly have to tell academicians that information is a valuable resource: knowledge is power. And yet it occupies a slum dwelling in the town of economics. Mostly it is ignored...." (p. 213). Twenty years later, Stigler would receive the 1982 Nobel Memorial Prize in Economics for his seminal studies on industrial structures with reference to the economics of information. A time lag almost three times as long can be inferred from the closing comment of Ronald Coase in his acceptance speech of the 1991 Prize "...it is a strange experience to be praised in my eighties for work I did in my twenties." Even with a Nobel Prize in hand, ideas can still be studiously ignored. Joseph E. Stiglitz, who won the 2001 Prize for the economics of asymmetric information, tells of his delight in 2008 upon discovering a pirated Chinese translation of his work "...being ignored is far worse than having one's property stolen, and I resolved that I would actually be much happier if they had stolen my intellectual property than if they had ignored me... researchers and academics want their ideas to be disseminated. They work quite hard, in fact, traveling all over the world to disseminate their ideas" ( $p$. 1696). For the many path-breaking economists whose work still resides in "the slum dwelling of the town," the participle modifier "studied" to describe "ignorance" may seem pusillanimous. Herman Daly writes in the preface to the second edition of Steady-State Economics (1991) that the first edition (1977) was "aggressively ignored" (p.xii); not one economics journal bothered to review the book despite its favorable reception among biologists.

Studied ignorance is not peculiar to economists. In the autobiography The Naturalist, E.O. Wilson comments that gene-culture co-evolution--a sophisticated mathematical model co-authored with physicist Charles J. Lumsden (1981)--has "simply languished, mostly ignored by biologists and social scientists alike...[nevertheless] I do not doubt for an instant that its time will come" (1994, p. 353). By the clock of Coase, Daly or even Stigler, Wilson seems impatient indeed: only 13 years had lapsed and not 20,24 , or 60 plus. With some digging, we suspect many more examples of studied ignorance or its synonyms will surface (e.g., "intriguing silence" (Boyle, 1992)) along with a hint of resentment from the scholars so ignored. No doubt the most infuriating manifestation of studied ignorance is a trumpeted discovery of what--lo and behold--has already been discovered! For the scholar being sucked down the memory hole, the trick is "to stay discovered" as the mathematician Larry Schepp famously quipped (Kolata, 2006).

The award of the 2001 Nobel Memorial Prize for the economics of asymmetric information indicates that the larger research program, viz., the economics of information, will stay discovered for quite some time. In the sociology of science, the year 2001 marks the arrival of the Kuhnian stage of "normal science" (1962, pp. 35-42) where applications are done routinely without controversy. Nevertheless, the non-economist in the Conference of the Parties to (COP) to the CBD cannot be expected to navigate normal-science economics or even recognize it as such. The economics literature is just too vast, unwieldy and jargon-laden; the mathematics is also intimidating. In contrast, the bulk of the ABS literature is written in a legal prose that eschews not only math but even the percentage symbol. The prevalent approach is "very legalistic" according to Ronnie Vernooy and Manuel Ruiz $(2012$, p. 6) who have accompanied twenty years of ABS discussion. A casual observer of the COPs would estimate that lawyers outnumber economists by three orders of magnitude, i.e., a thousand fold. [Note 1] Is it "fair and equitable" to expect attorneys to plumb an unfathomable economics literature?

Stephen A. Marglin argues in The Dismal Science that economics-the-enterprise "is better characterized by the content of elementary texts than by what goes on at the frontiers of economic theory" $(2008$, p. 5). The truth of that statement is nothing new. Canonical textbooks have been nodes in policymaking ever since Alfred Marshall first published Principles of Economics in 1890. Because a year of introductory economics is foundational in legal or diplomacy education worldwide, it is quintessentially fair and equitable to expect lawyers and diplomats to be cognizant of concepts found in the first two hundred pages of an introductory text. When did the topic "economics of information" surface in, say, ECONOMICS by Samuelson and later co-authored by Nordhaus? As of 2010, the book is in its $19^{\text {th }}$ edition and has been translated into at least 21languages. [Note2]

A survey of the 19 editions of ECONOMICS shows that the economics of information appears as its own section for the first time in the $17^{\text {th }}$ edition published in 2001. The aspect of the economics of information which holds the most relevance to the CBD is the asymmetric cost structure of creating and reproducing information. Samuelson and Nordhaus describe the asymmetry thus:

Information is expensive to produce but cheap to reproduce. To the extent that the rewards to invention are inappropriable, we would expect private research and development to be underfunded...special laws 
governing patents [and so on]...create intellectual property rights. The purpose is to give the owner special protection against the material's being copied and used by others without compensation to the owner of the original creator...Why would governments actually encourage monopolies?...By creating property rights, governments encourage artists and inventors to invest time, effort, and money in the creative process (2005, p. 195).

Although legal education explores analogies, the lawyer and/or diplomat may be tempted to dismiss what they learned in a required course from another discipline. Even if we concede the pitiful state of economics education (Monaghan, 2003) and acknowledge its ideological bent (Berrett, 2012; Johnson 2012), the notion of asymmetric costs nevertheless enters elsewhere in the core curriculum of the lawyer and/or diplomat: Constitutional Law I \& II. For example, Stiglitz cites Thomas Jefferson to make the point about negligible marginal costs: "that knowledge was like a candle: when one candle lights another it does not diminish the light of the first candle." To make the ancillary point about tremendous fixed costs, he then alludes to the US Constitution, ratified in 1787: "We not only tolerate... restricting the use of knowledge, which creates monopoly power, but we sanction it: it is part of our legal framework because we hope it will promote innovation" (2008).

The year 2002 marks one year since the Nobel Memorial Prize for the economics of asymmetric information and the first appearance of the economics of information as a section in ECONOMICS, ten years since the signing of the CBD, forty-one years since the publication of Stigler's landmark article and two hundred and fourteen years since the ratification of the US Constitution with Article 1 Section 8 Clause 8 "To promote the Progress of Science and useful Arts, by securing for limited Times to Authors and Inventors the exclusive Right to their respective Writings and Discoveries". In sum, the existence of the economics of information is preponderant. From 2002 onward, the lack of due diligence is not a credible explanation for failure to apply the economics of information in the $\mathrm{CBD}$ once one recognizes genes as information. Far more credible is opposition to the policy implied by the application of the economics of information, viz. the cartelization of biodiversity and associated traditional knowledge (Vogel, 1997a, 2007a; Vogel (ed.) 2000).

\section{Benchmark Dates for Genes as Information}

As of 1 January 2012, a Google search reveals approximately 19 million hits for "genetic information" yet the term does not appear once in the CBD. By transitivity in the construction of the treaty language, "genetic resources" are "material" (Art. 2), which is exactly opposite to the immaterial nature of information. Was "genetic information" a little circulating concept circa 1992? The answer is so firmly negative that the question appears rhetorical. Francis Crick, co-discoverer of DNA, published the central dogma of molecular biology in Nature in 1970 and ever since "genetic information" has been ubiquitous in the literature along with related terms such as "copying" and "translation." Interestingly, the metaphor was not original to Crick. The general concept of information in heredity can be inferred in What is Life? published in 1944 where Erwin Schrödinger writes about "code-script" and "miniature code".

Well before the $1992 \mathrm{CBD}$, the recognition of genes as information was levering whole industries. The gene sequence repository "Genbank", maintained by the National Center for Biotechnology Information, grew exponentially since its launch in 1982 (US Department of Health and Human Services, 2008). With the genomic revolution of the 1980s, the word "bioinformatics" morphed in meaning to encompass the application of computer science to the management of biological data (BISTIC, 2000). Other neologisms emerged in the parlance of biotechnology that are tightly associated with information: genomics, proteomics, metabolomics, Barcoding (of Life) and biomimicry. And the list continues to grow with the emerging "omics" fields of studies (e.g., exomics, lipidomics, phenomics).

Did a synthesis of the economics of information and genetic information occur to anyone in the context of the CBD circa 1992? Like "genetic information," the answer is definitively affirmative. In 1992, the noted legal scholar Daniel Boyle published "A Theory of Law and Information: Copyright, Spleens, Blackmail, and Insider Trading" and opens with the salvo "It is hard, nowadays, to find a piece of futurology that doesn't say we are entering an information age." He refers specifically to "genetic information" twenty-two times and subtitles section IV "The Economics of Information". Although Boyle represents due diligence par excellence in synthesizing a diverse literature, he nevertheless stops short of applying the asymmetric cost structure of artificial information ("expensive to make and cheap to copy") to "genetic information" for what was still a "proposed treaty on genetic sovereignty". Joseph Henry Vogel did the application in Privatisation as a Conservation Policy published in 1992(a) and re-published in 1994(a) as Genes for Sale. Vogel reduces biodiversity first to "genetic information" and then to "natural information" (p. 38) thereby allowing for the phenotypic expressions (p.43) that are now associated with the word "biomimicry". Over the next twenty years, 
Vogel and co-authors explored additional aspects of the economics of information applied to natural and the associated artificial information in both popular and refereed venues and in several languages, (Vogel, 1992b, 1994b, 1994c, 1995, 1997b, 1999, 2004, 2005, 2007b, 2008a, 2008b, 2012; Vogel (ed.) 2010, Vogel and Ingram, 1993; Vogel, Robles, Gomides and Muñíz, 2008; Vogel and Ruiz, 2010; Marrero-Girona and Vogel, 2012; Ruiz, Vogel and Zamudio, 2010; Vernooy et al., 2010).

An unambiguous policy implication emerges from the application of the economics of information to genetic information: cartelization of biodiversity eliminates free and easy-riding, the latter defined as "shoulder[ing] some of the cost [of habitat conservation] but... less than the average cost" (Vogel, 1994a, p. 29).

\section{Methodology for Searches}

E.O. Wilson (1992, p. 280) estimates that one species goes extinct every 20 minutes. How much time should be allowed for "the economics of information" to enter the public debate about ABS? The previously cited lags of 60 plus, 24, and 20 years for economists, or even 13 years for biologists are absurd in the age of the internet. By Wilson's clock for extinction, such time lags translate into 1,576,800 plus, 630,720 and 525,600 extinct species. In light of instantaneous telecommunications and the urgency to settle ABS, a ten-year lapse $(262,800$ species extinct) is more than reasonable time for due diligence. We search the literature for the years 2002 to 2011 which is also ten years after the signing of the $1992 \mathrm{CBD}$. Our search is for the idea of viewing genetic resources as information and applying the established economics of information to the question of ABS. Alas, search engines do not search ideas. They search words. Which combination of words is indicative of the salient implication of the economics of information for the CBD?

The "Convention on Biological Diversity" is also known as the "Convention on Biodiversity," the "Convention of Biodiversity" and the "Biodiversity Convention". Four names circulate to express the title of the convention. When the idea to search is abstract, the possibilities of expression are limited only by one's imagination. Without saying "economics of information" one can express its essential relevance through "asymmetric cost structure", "asymmetric costs", "high fixed costs and low marginal costs", "oligopoly", "oligopolization", "cartel", "cartelization" and so on. Not only will the mathematical product explode of all the synonyms but casting a broad net will also pick up false positives. For example, the policy implication from the economics of information for ABS is a payment of "rents" where "rent" is defined as the value above that which obtains in a purely competitive market. David Simpson et al. (1996, p. 167) have written about "rents" in the general context of bioprospecting without reflecting on how the asymmetric cost structure between access to genetic resources and the conservation of habitats impacts intellectual property rights. One would have to cull, article by article, such false positives.

It gets worse. The most problematic treaty language for the purpose of searches is "access to genetic resources" and "the fair and equitable sharing of the benefits." The phrase is so cumbersome that the vast majority of authors compress the phrase to "access to genetic resources and the sharing of benefits" or the more mellifluous "access to genetic resources and benefit sharing" (see Table 1 of Marrero-Girona and Vogel, 2012). The acronym "ABS" is of no help as it coincides with a common abbreviation for the word "abstract" as well as "American Bobtail Shorthair [cats]", "Australian Bureau of Statistics", "acrylonitrile butadiene styrene" and "anti-lock braking system". Fortunately, no matter how the idea of ABS is expressed, the words "benefits" and "sharing" must appear. So we use "benefits" and "sharing" as keywords in lieu of "access to genetic resources" and "the fair and equitable sharing of benefits" (Graphs 1 and 2).

Recognition of genes as information is best captured by "genetic information" (Graphs 3 and 4). Such recognition can also be inferred in the many words associated with "genomics", viz., "proteomics", "metabolomics", "Barcode of Life", etc. Although it is possible that someone writes about "genomics" without referring to "genetic information", it seems unlikely that one writes about "proteomics", etc. without referring to "genomics". Therefore, we limit the searches to just "genetic information" or "genomics" in the string of keywords (Graphs 5 and 6).

Mention of genomics in a text about ABS is evidence prima facie that the author(s) perceive genes as information. We contend that failure to mention the implications of the economics of information is studied ignorance.

\section{Hits in Google, Google Scholar and LexisNexis}

In "The Research Bust", Mark Bauerlein (2011) laments the paucity of citations from search engines: "these are blunt, partial instruments, and a full assessment requires qualitative judgments. But they do initiate a process that is necessary at a time of scarce resources" (p. B4).We agree wholeheartedly. A full assessment of the global 
literature on the "economics of information" as applied to ABS would require qualitative judgments of thousands of hits and be beyond our scarce resources. Moreover, the exercise is not necessary inasmuch as our aim is simply to initiate a process about the studied ignorance of the "economics of information" in the ABS discussion. By comparing the hits from the three search engines for the inclusion and exclusion of the "economics of information", we take stock. Because "[m]ost law-review and journal articles are infrequently cited" (Edwoof, 2012) we expect the fewest hits from LexisNexis; because the general "Google" goes beyond a "discourse among experts" (Lopez, 2012), we expect many more hits from "Google" than from "Google Scholar". The results wildly outstrip our low expectations and are presented in coded bar diagrams to facilitate comparisons (see Graphs 1 -6).

\section{Numbers vs. Narratives}

"A search engine works by sending out a spider to fetch as many documents as possible" (Webopedia.com, 2012). As the definition makes clear, the resulting indices from search engines are not 100\% accurate. For example, "The Economics of Information, Studiously Ignored in the Nagoya Protocol on Access and Benefit Sharing" (Vogel, et al. 2011) incorporates all of the keywords of Search 1 in Table 1 but the article does not appear in Google Scholar despite open-access of Law Environmental and Development Journal. However, the article does register in Google and LexisNexis. Even if the engines are imprecise by two orders of magnitude, i.e., a factor of a hundred, the evidence is still overwhelming: "the economics of information" is almost completely ignored in the discussion of ABS (Graph 1). When "the economics of information" is excluded, hits soar between 10,000 and 90,000 per year in Google and between 1000 and 1500 in Google Scholar (Graph 2). The hits in LexisNexis are so low that they visually disappear in the bar diagrams. Despite the imprecision of such searches, we agree with Bauerlein that engines provide "a significant indicator of a deep kind of academic reception" (2012 p. B23).We see no steady increase in the bar diagrams for the economics of information as we track the ten year period beginning 1 January 2002 and ending 31 December 2011.

Numbers about due diligence and studied ignorance may not persuade as effectively as an anecdote or two. Scientists generally berate anecdotes for committing the fallacy of small sample size (hasty generalization). However, the "norm in scholarship" is "highly skewed [with] long tailed distributions of citations" (Brown, 2012, p. B22), which integrates with the general theme of Robert H. Frank's The Winner-Take-All Society: Why the Few at the Top Get So Much More Than the Rest of Us (1995). We have selected two narratives from veritable superstars so extreme in studied ignorance or lack of due diligence that the keywords of Graphs 1-6 would not pick up either text. The passages are drawn from The Future of Life by E.O. Wilson (2002) and "Economic Foundations of Intellectual Property Rights [IPRs]" by Joseph E. Stiglitz (2008), which register, respectively 714 and 49 hits in Google Scholar as of January 2012.

Stiglitz writes of "ambivalent feelings about intellectual property" (2007 p. 1695) and reflects on "biopiracy" defined as "the patenting of drugs and other products based on traditional knowledge"(p. 1704). He advocates a balancing of rights, which is a common position in the literature (see, May, 2010). However, Stiglitz fails to perceive imbalance between monopoly IPRs over artificial information and unbridled competition over natural information. Why wasn't the asymmetry apparent?

A clue exists in unpacking the following sentence: "This is not, of course, just a matter of TRIPS [Trade Related Intellectual Property Rights], but also of the Biodiversity Convention--the United States has refused to sign the convention that was intended to provide some protection for their biodiversity largely because the drug companies do not want to pay for the use of genetic materials obtained from developing countries" (p. 1719). Error \#1: The Convention on Biological Diversity is indeed a biodiversity convention but should only be so identified in lower case. Error \#2: on 4 June 1993 the then newly-elected President William J. Clinton signed the CBD. Error \#3: drug companies routinely paid--before the CBD--for the use of genetic materials obtained from developing countries (ten Kate and Laird, 1999, p.68). Error \#4: "genetic resources" is the common expression for the object of access and not "genetic materials." A plausible assertion that corrects Errors \#3 and \#4 would be "the drug companies do not want to pay [a rent] for [natural information] obtained from developing countries".

Stiglitz has no reason whatsoever to studiously ignore the economics of information. As a 2001 Nobel Memorial Laureate for the economics of asymmetric information, he has every reason to weigh in the ABS debate. So, the fact that he (1) misnames the 1992 Convention on Biological Diversity, (2) does not mention once ABS or its synonyms, (3) refers to genetic resources as genetic material,(4) confuses signature of the treaty with ratification and (5) conflates payment for genetic material with economic rents for genetic resources, indicates a shocking lack of due diligence. Unawareness that genes are information seems to be the cause. In a footnote, Stiglitz marvels "I am always astounded by differences in what people know about" (p. 1709). 
Oh that we could dismiss The Future of Life as simply a lack of due diligence! Careful reasoning exudes from every page and twenty pages of endnotes reveal painstaking research. To extoll bioprospecting as a source for funding conservation, Wilson describes a poisonous dart frog (Epipedobates tricolor) that has led to promising drug discovery (pp. 121-123). Although Wilson cites the CBD elsewhere (p. 165), he does not cite it in the context of E. tricolor. Consequently he also does not cite ABS which is a principle objective of the CBD. How could one painstakingly research E. tricolor without being bombarded with ABS? Rightly or wrongly, the physical removal of specimens of E. tricolor from Ecuador has become emblematic of biopiracy (Bravo and Gallardo, 1998; for a comprehensive review, see Angerer 2011). As of January 2012, "biopiracy" and "dart frog" generates 1.3 million hits in Google. For Google Scholar, the book Biopiracy (Shiva, 1997) scores some 940 hits and by comparison, The Future of Life, 714 .

Wilson writes that "bioprospecting can serve both mainstream economics and conservation when done on a firm contractual basis" (p. 127). As previously argued, by 2001 the economics of information was "mainstream economics". The implication from the asymmetric cost structure of information is diametrically opposite Wilson's assertion: conservation is ill served "when [bioprospecting is] done on a firm [bilateral] contractual basis" as rents are eliminated through competition. Nevertheless, Wilson implies that rents for the transnationals are OK: "of equal importance to the pharmaceutical companies, these analogs [to the natural prototypes] can be patented" (p. 120). Any aficionado of Wilson will start to dismay. "In 1998 Diversa Corporation signed on with Yellowstone National Park to continue bioprospecting the hot springs for biochemicals from thermophile microbes. Diversa pays the park $\$ 20,000$ yearly to collect the organism for study, and a fraction of the profits generated by commercial development" (italics ours, p. 127). The fraction is undisclosed and a similar circumlocution appears on the next page with respect to GlaxoWellcome: "with part of the profits pledged to the support of Brazilian science" (italics ours, p. 128). Undisclosed fractions or parts can become infinitesimally small. Wilson goes on to say how the funds will be earmarked to "promote conservation of the unique microbes and their habitat, as well as for basic scientific research and public education" (p. 127), even though "most economists...have been skeptical about earmarking...in general, it has not worked very well" (McCleary, 1991, p. 81).

Wilson entitles Chapter Five "How Much is the Biosphere Worth? (p. 103-128) and even uses the phrase "genetic information" (p. 132). Why then his studied ignorance of the economics of information? The facile answer would be that Wilson serves on the "International Advisory Board" of the National Institute of Biodiversity (INBio) of Costa Rica which "search[es] for new pharmaceuticals in Costa Rica's rainforests and other natural habitats" (p. 127). Any brooking of the economics of information calls into question the correctness of INBio to negotiate bilaterally (Vogel, 1997a). However, we do not believe that the facile answer is correct. Biopiracy is derogatory and frames the scientist as villain in the narrative (Marrero-Girona and Vogel, 2012; Lakoff 2008). Scientist as hero freely associates with Wilson's hope "that the problem [viz., sustainability] can be solved" (p. 189). So, by ignoring ABS, Wilson can ignore biopiracy and detour the neural pathway to cynicism.

\section{Conclusion}

Trillion-dollar mistakes such as the weapons of mass destruction and financial derivatives were duly warned and studiously ignored. One thinks of the meticulous work of Hans Blix and Nouriel Roubini. The absence of the economics of information in the ABS discussions integrates with such recent history-in-the-making. We have monitored and tracked the economics of information in the published literature about the CBD. The results are overwhelming: studied ignorance for the years 2002-2011 is on a scale of three orders of magnitude in Google Scholar and four in Google. In other words, for every text that cites the economics of information, 1000 to 10,000 articles do not.

In Consilience, Wilson comments that "science needs the intuition and metaphorical powers of the arts" (1998, p. 210). English playwright, novelist, and short story writer W. Somerset Maugham wrote "[just] as nothing is more dead than a love that has burnt itself out, so no subject is less interesting to an author than one upon which he has said his say" (1968, p. ix). The Earth Summit convened in June 1992 and launched the CBD which was ratified the following year. From the beginning, the policy implications of the economics of information for ABS were articulated over and over again: users in biotechnology should pay an economic rent to the countries of origin. Having had their say, one would think that the advocates of the economics of information would heed Maugham's advice and move on to other subjects that are more interesting. Yet many will persist simply because mass extinction persists, mercilessly. One can only hope that this first installment of monitoring and tracking helps to make it the last. 


\section{Acknowledgement}

Thanks are especially due to Liam Burke for research assistance. Comments to early drafts by Betzaida Ortiz-Carrión, Paul Bayman and Maritza Stanchich were also much appreciated. The usual disclaimer applies.

\section{References}

Angerer, K. (2011). Frog tales-on poison dart frogs, epibatidine, and the sharing of biodiversity. Innovation: The European Journal of Social Science Research, 24(3), 353-369. http://dx.doi.org/10.1080/13511610.2011.592061

Bauerlein, M. (2011). The research bust. The Chronicle Review, B4.

Bauerlein, M. (2012). Conversation 'measuring the value of Literary research' Mark Bauerlein responds. The Chronicle Review, B23.

Berrett, D. (2012). Economists push for a broader range of viewpoints in their field. The Chronicle of Higher Education, A11-A12.

BISTIC (Bioinformatics and Bioinformatics and Computational Biology Committee). (2000). NIH working definition of bioinformatics and computational biology. Retrieved from http://www.bisti.nih.gov/docs/CompuBioDef.pdf

Boyle, J. (1992). A theory of law and information: copyright, spleens, blackmail, and insider trading. California Law Review, 80(6), 1413, 1461-1470. Retrieved from http://www.law.duke.edu/boylesite/law\&info.htm

Bravo, E. \& L. Gallardo. (1998). Biopiratería/Biopiracy Ecuador: biopiracy of Epipedobates tricolor. GRAIN. Retrieved from http://www.grain.org/article/entries/1885-biopiratera-a-biopiracy-ecuador

Brown, C. T. (2012). Conversation 'measuring the value of literary research', Letter to the Editor.The Chronicle Review, B22.

Coase, R. (1991). Lecture for the Sveriges Riksbank Prize in Economic Sciences in Memory of Alfred Nobel. Retrieved from http://www.nobelprize.org/nobel_prizes/economics/laureates/1991/coase-lecture.html

Crick, F. (1970). Central dogma of molecular biology. Nature, 227, 561-563. Retrieved from http://profiles.nlm.nih.gov/ps/access/SCBCCH.pdf

Daly, H. (1977). Steady-state economics. San Francisco: W.H. Freeman and Company.

Daly, H. (1991). Steady-state economics (2nded.). Washington, D.C.: Island Press.

Edwoof. (2012). Conversation 'Measuring the Value of Literary Research', Letter to the Editor. The Chronicle Review, B22.

Frank, R. H. (1995). The winner-take-all society. New York: Free Press.

Johnson, R. (2012). Economists: a profession at sea. TIME Magazine. Retrieved from http://business.time.com/2012/01/19/economists-a-profession-at-sea/

Kolata, G. (2006). Pity the scientist who discovers the discovered. The New York Times. Retrieved from http://www.nytimes.com/2006/02/05/weekinreview/05kolata.html?pagewanted=print

Kuhn, T. (1962). The structure of scientific revolutions. Chicago: University of Chicago Press.

Lakoff, G. (2008). The political mind. New York: Penguin.

Lopez, R.O.P. (2012). Conversation 'measuring the value of literary research', Letter to the Editor. The Chronicle Review, B22.

Lumsden, C. \& E. O. Wilson. (1981). Genes, mind, and culture. Cambridge: Harvard University Press.

Marglin. S. (2008). The dismal science. Cambridge: Harvard University Press.

Marrero-Girona, G. \& J. Vogel. (2012). Can 'monkey business' resolve the most contentious issue in the Convention on Biological Diversity? International Journal of Psychological Studies, 4(1), 55-65. http://dx.doi.org/10.5539/ijps.v4n1p55

Marshall, A. (1890). Principles of economics. London: Macmillan \& Co., Ltd.

Maugham, W. S. (1968), Theatre. London: Heron Books.

May, C. (2010). The global political economy of intellectual property rights (2nded.). USA: Routledge. 
McCleary, W. (1991). The earmarking of government revenue: a review of some World Bank experience. World Bank Research Observer, 6(1), 81-104.

Monaghan, P. (2003). Taking on 'rational man': dissident economists fight for a niche in the discipline. The Chronicle of Higher Education, 49(20), A12.

Nelson, C. \& S. Watt. (1999). Academic keywords. New York: Routledge, 1999.

Ruiz, M., J. Vogel, \& T. Zamudio. (2010). Logic should prevail: a new theoretical and operational framework for the International Regime on Access to Genetic Resources, and the Fair and Equitable Sharing of Benefits. Initiative for the Prevention of Biopiracy, Research Documents, 5(13).

Samuelson, P. \&W. Nordhaus. (2001). ECONOMICS (1 $7^{\text {th }}$ ed.). New York: McGraw-Hill.

Samuelson, P. \&W. Nordhaus. (2005). ECONOMICS (1 $8^{\text {th }}$ ed.). New York: McGraw-Hill.

Schrödinger, E. (1944). What is life? Cambridge: Cambridge University Press.

Shiva, V. (1997). Biopiracy. Cambridge: South End Press.

Simpson, R. D., R.A. Sedjo\& J. W. Reid. (1996). Valuing biodiversity for use in pharmaceutical research. The Journal of Political Economy, 104(1), 163-185.

Skousen, M. (1997). The perseverance of Paul Samuelson's Economics. Journal of Economic Perspectives, 11(2), 137-152.

Stigler, G. (1961). The economics of information. Journal of Political Economy, 69, 213-225.

Stiglitz, J. (2008). Economic foundations of intellectual property rights. Duke Law Journal, 57, 1693-1724.

ten Kate, K., \& S.A. Laird. (1999). The commercial use of biodiversity. London: Earthscan Publications, Ltd.

US Department of Health and Human Services. (2008). GenBank celebrates 25 years of service with two-day conference. NIH News. Retrieved from http://www.nih.gov/news/health/apr2008/nlm-03.htm

Vernooy R, E. Haribabu, M. Muller, J. Vogel, P. Hebert, et al. (2010). Barcoding life to conserve biological diversity: beyond the taxonomic imperative. PLoS Biol 8(7):e1000417. Retrieved from http://www.plosbiology.org/article/info: doi/10.1371/journal.pbio.1000417

Vernooy, R \& M. Ruiz. (2012). Introduction: widening the horizon. In M. Ruiz and Vernooy, R. (Eds.), The custodians of biodiversity: sharing access to and benefits of genetic resources(pp. 3-9). New York: Earthscan.

Vogel, J \& G. B. Ingram. (1993). Biodiversity vs. genetically coded functions: the importance of definitions in conservation policy. Review of European Community and International Environmental Law, 2(2), 121-125.

Vogel, J. (1992a). Privatisation as a conservation policy. Melbourne, Australia: CIRCIT.

Vogel, J. (1992b). A privatização como uma política de conservação. In E. Teixeira (Ed.) Política Agrícola $e$ Desenvolvimento (pp. 125-131).Viçosa, Brazil: UFV-FAPEMIG.

Vogel, J. (1994b). NAFTA and the Theory of Second Best. DIVERSITY, 9(4) \& 10(1), 79-80.

Vogel, J. (1994c). Privatisation as a conservation policy: Vogel replies to Revington.World Rainforest Report 27, $32-33$

Vogel, J. (1995). The market alternative to the valuation of biodiversity: the example of Ecuador. Association of Systematics Collection Newsletter, 23(5), 66-70.

Vogel, J. (1997a). White Paper: the successful use of economic instruments to foster the sustainable use of biodiversity: six cases from Latin America and the Caribbean. Biopolicy Journal, 2(5) (PY97005). http://www.bioline.org.br/request?py97005

Vogel, J. (1997b). Bioprospecting and the justification for a cartel. Bulletin of the Working Group on Traditional Resource Rights, 4, 16-17.

Vogel, J. (1999). The Convention on Biological Diversity and equitable benefit sharing: an economic analysis. In D. A. Posey (Ed.) Cultural and spiritual values of biodiversity: a complementary contribution to the Global Biodiversity Assessment(pp. 530-531). Nairobi, Kenya, United Nations Environmental Programme.

Vogel, J. (2004). Nada en bioprospección tiene sentido excepto a la luz de la economía. Revista Iberoamericana $\begin{array}{lllll}\text { de Economía Ecológica } & \text { (REDIBEC) } & 1 . & \text { Retrieved from }\end{array}$ http://www.redibec.org/archivos/revista/articulo4.pdf 
Vogel, J. (2005). Sovereignty as a Trojan horse: How the Convention on Biological Diversity morphs biopiracy into biofraud. In B. A. Hocking (Ed.) Unfinished constitutional business? Rethinking indigenous self-determination (pp. 228-247). Australia: Aboriginal Studies Press.

Vogel, J. (2007a). Reflecting financial and other incentives of the TMOIFGR: the biodiversity cartel. In M. Ruiz and I. Lapeña (Eds.) .A Moving Target: Genetic Resources and Options for Tracking and Monitoring their International Flows(pp. 47-74). Gland, Switzerland: IUCN. Retrieved from http://data.iucn.org/dbtw-wpd/edocs/EPLP-067-3.pdf Retrieved in Spanish from http://cmsdata.iucn.org/downloads/eplp_67_3_sp.pdf Retrieved in French from http://cmsdata.iucn.org/downloads/eplp_67_3_fr.pdf

Vogel, J. (2007b). From the 'tragedy of the commons' to the 'tragedy of the commonplace': analysis and synthesis through the lens of economic theory. In C. McManis (Ed.), Biodiversity \& law (pp. 115-136). London: Earthscan.

Vogel, J. (2008a). The unspeakable economics of ABS. Bridges, ICSTD, 12(4). Retrieved in http://ictsd.net/i/news/bridges/27572/

Vogel, J. (2008b). Nothing in bioprospecting makes sense except in the light of economics. In N. Sunderland, P. Graham, P. Isaacs, and B. McKenna (Eds.), Toward humane technologies: biotechnology, new media and ethics (pp. 65-74). Rotterdam: Sense Publishers Series.

Vogel, J. (2012). Epilogue: Architecture by committee and the conceptual integrity of the Nagoya Protocol. In M. Ruiz and R. Vernooy (Eds.), The custodians of biodiversity: sharing access to and benefits of genetic resources (pp. 181-188). New York: Earthscan. Retrieved in http://idl-bnc.idrc.ca/dspace/bitstream/10625/47481/1/IDL-47481.pdf

Vogel, J. (Ed.) (2000). The biodiversity cartel. Quito, Ecuador: CARE.

Vogel, J. (Ed.) (2010). The museum of bioprospecting, intellectual property, and the public domain. London: AnthemPress, 2010.

Vogel, J. \& M. Ruiz. (2010). ¿Prevaleció la lógica en el WG-ABS9? El emergente Régimen Internacional de Acceso a los Recursos Genéticos y la Distribución Justa y Equitativa de Beneficios. In Vitulia Ivone (Ed), Biodiversidad, biotecnologías y derecho: un crisol para la sustentabilidad (pp. 217-251). Rome: ARACNE.

Vogel, J. \& M. Ruiz. (2010). Wronged by the wrong language: the International Regime on Access and Benefit Sharing. BRIDGES ICTSD. Retrieved in http://ictsd.org/i/library/90194/ Retrieved in Portuguese from http://www.migalhas.com.br/dePeso/16,MI123575,91041-Equivocos+e+tropecos + na + escolha + da + Linguag

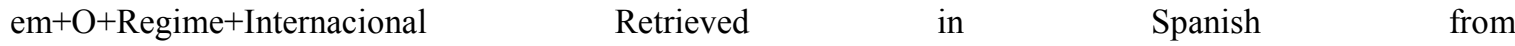
http://la.migalhas.com/mostra_noticia_articuladas.aspx?cod=149013

Vogel, J., C. Gomides, J. Robles, \& C. Muñiz (2008). Geopiracy as an emerging issue in intellectual property rights: the rationale for leadership by small states. Tulane Environmental Law Journal 21, 391-406.

Vogel, J., N Álvarez-Berrío, N. Quiñones-Vilche et al. (2011). The economics of information, studiously ignored in the Nagoya Protocol on Access and Benefit Sharing. Law Environment and Development (LEAD) Journal (7/1), 51-65. Retrieved in http://www.lead-journal.org/content/11052.pdf Retrieved in Spanish from http://www.lead-journal.org/content/11052a.pdf Retrieved in Portuguese from http://www.lead-journal.org/content/11052c.pdf Retrieved in French from http://www.lead-journal.org/content/11052b.pdf Retrieved in Arabic from http://www.lead-journal.org/content/11052d.pdf Retrieved in Chinese from http://www.lead-journal.org/content/11052e.pdf

Vogel, J.H. (1994a). Genes for sale. New York: Oxford University Press.

Webopedia.com. (2012).A word definition from Webopedia Computer Dictionary. Retrieved in http://www.webopedia.com/TERM/S/search_engine.html

Wilson, E.O. (1992). The diversity of life. New York: W.W. Norton \& Company.

Wilson, E.O. (1994). The naturalist. Washington, D.C.: Island Press.

Wilson, E.O. (1998). Consilience. New York: Knopf.

Wilson, E.O. (2002). The future of life. New York: Vintage Books. 


\section{Notes}

Note 1. The estimate is based upon the impressions by the third author who has participated as either an advisor in the Ecuadorian delegation or an academic observer for the Facultad Latinoamericana de Ciencias Sociales-Ecuador and the University of Puerto Rico-Río Piedras in COPII, COPIII, COPIV, COPVIII, COPIX and COPX as well as several preparatory meetings from 1994 through 2010.

Note 2. Mark Skousen (1997, p. 137) reports that ECONOMICS appears in 41 languages. However, www.worldcat.org lists only 21 translated editions worldwide. Regardless of the true number, the textbook is a classic in university education.

Graphs 1 and 2

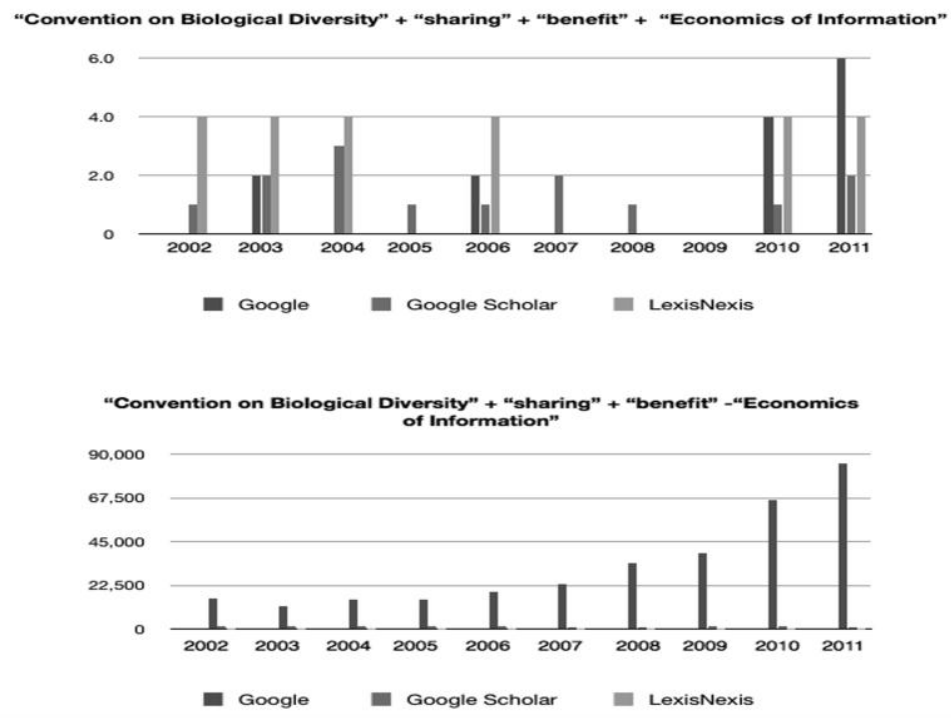

Graphs 3 and 4
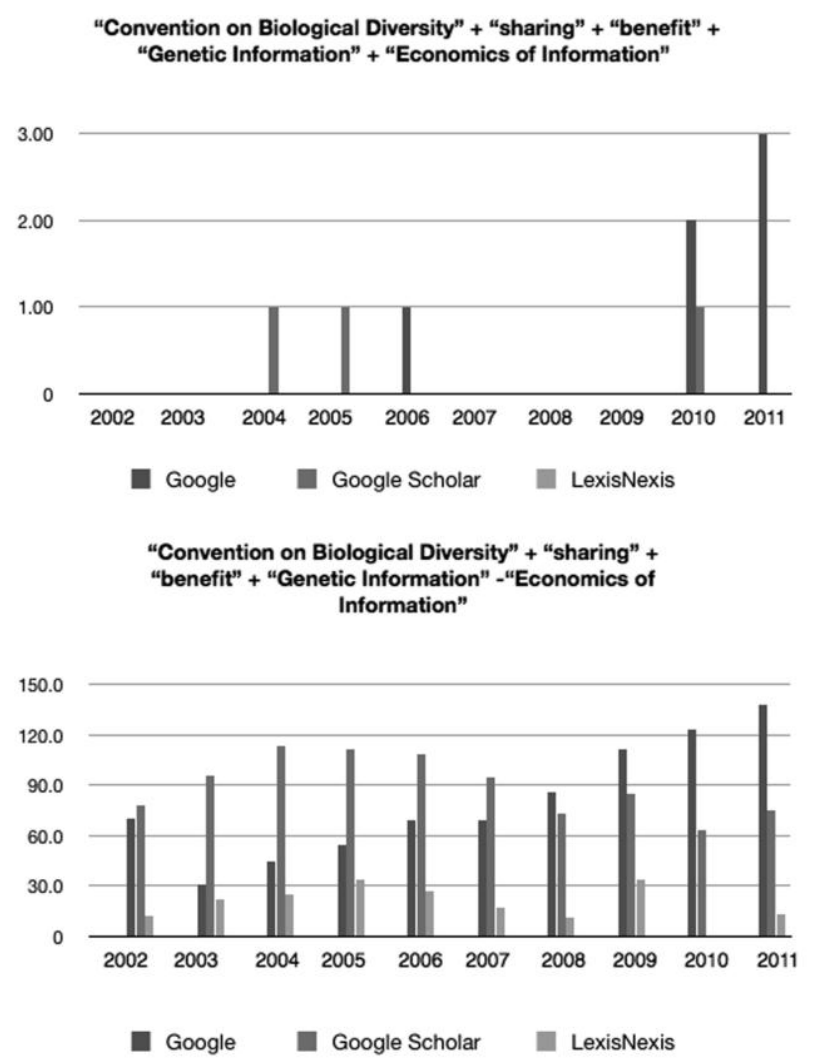
Graphs 5 and 6 "Convention on Biological Diversity" + "sharing" + "benefits" +
"Genomics" + "Economics of Information"

2.0

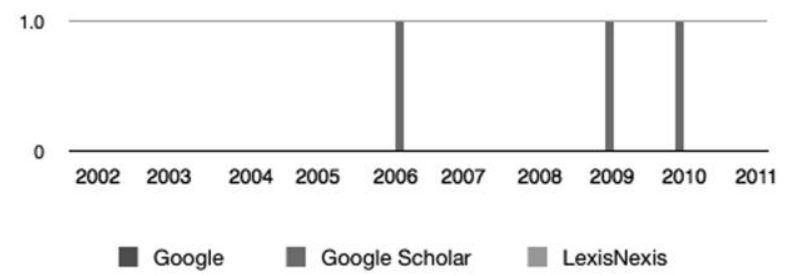

"Convention on Biological Diversity" + "sharing + "benefits" + "Genomics" -"Economics of Information"

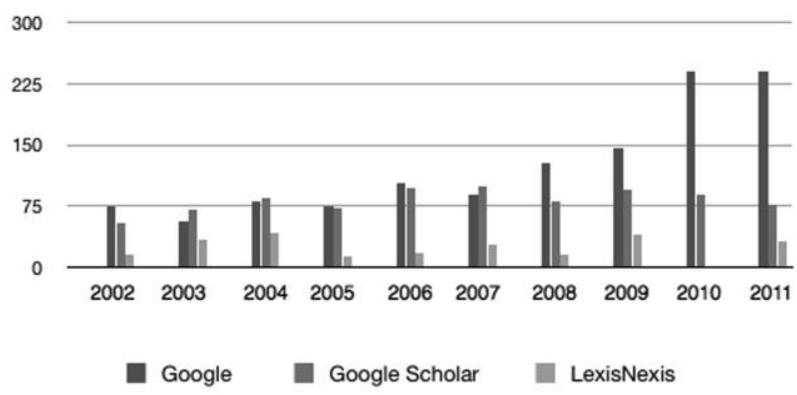

